\title{
OWNERSHIP STRUCTURE OF FAMILY BUSINESS GROUPS
}

\author{
Wlamir Xavier \\ https://orcid.org/0000-0001-8106-1822 \\ Silvio Parodi Oliveira Camilo \\ https://orcid.org/0000-0001-5917-1283 \\ Rosilene Marcon \\ https://orcid.org/0000-0002-0478-7715 \\ Frederick Greene \\ https://orcid.org/0000-0001-8152-4284
}

Recebido em: 6 dez. 2020

Aceito em: 13 dez. 2020

Como citar este artigo: XAVIER, W.; PARODI CAMILO, S.; MARCON, R.; GREENE , F. .

OWNERSHIP STRUCTURE OF FAMILY BUSINESS GROUPS: ESTRUTURA DE PROPRIEDADE DE FAMILY BUSINESS GROUPS. Revista Visão: Gestão Organizacional, Caçador (SC), Brasil, v. 9, n. 2, p. 240-253, 2020. Disponível em: https://doi.org/10.33362/visao.v9i2.2470.

Abstract: This study seeks to analyze the relationship between the ownership structure of Family Business Groups and the institutional environment. Family Business Groups prevail in emerging countries as diverse organizational structures that aggregate various companies under the control of a family or a reduced number of people. This economically relevant structure is responsible for a significant share of countries' Gross Domestic Product and frequently congregates the largest private companies in their respective countries. Institutional reforms have been implemented in emerging economies in order to support the integration of other nations from a trade perspective. This paper contributes to the literature by developing propositions on the effect of institutional reforms on the ownership structure of Family Business Groups.

Keywords: Family Business Groups. Ownership Structure. Market reforms.

\section{ESTRUTURA DE PROPRIEDADE DE FAMILY BUSINESS GROUPS}

Resumo: Este estudo busca analisar a relação entre a estrutura de propriedade de Family Business Groups e o ambiente institucional. Family Business Groups predominam em países emergentes como estruturas organizacionais variadas que agregam várias empresas sob o controle de uma família ou um número reduzido de pessoas. Essa estrutura economicamente relevante é responsável for uma parcela significativa do Produto Interno Bruto dos países e frequentemente congrega as maiores empresas privadas em seus respectivos países. Reformas institucionais foram implementadas em economias emergentes a fim de apoiar a integração de outras nações sob uma perspectiva comercial. Este artigo contribui com a literatura ao desenvolver proposições sobre o efeito de reformas institucionais na estrutura de propriedade de Family Business Groups.

Palavras-chave: Family Business Groups. Estrutura de propriedade. Reformas de mercado. 


\section{INTRODUCTION}

Family Business Groups (FBG) represent a very common type of enterprise setup in various emerging countries (GHEMAWAT; KHANNA, 1998; KHANNA; YAFEH, 2007; SCHNEIDER, 2008). This type of structure is responsible for a significant percentage of the Gross Domestic Product (GDP) and frequently congregates the largest private companies of the country where it is based (CASANOVA, 2009; GHOSH, 2010; KHANNA; PALEPU, 1997; 2000A; KHANNA; RIVKIN, 2001). In China, for example, the relevance of FBG is evidenced by their contribution to the country's industrial production, which is close to 60\% (YIU; BRUTON; LU, 2005). Despite intercountry variations, FBGs are generally a diversified conglomerate of companies acting coordinately, which is controlled by a family or by very few people.

A working definition of FBG for the purpose of this article is needed, as there is no consensus on how to define the boundaries of an FBG. The approach of this study considers an FBG to be a set of legally independent and diverse firms operating coordinately under centralized control and ownership. A similar criterion was adopted by several empirical studies, such as Guillén (2000) and Khanna and Palepu (2000a). Though not comprehensive, this definition helps to state FBG boundaries, but it does not encompass informal ties, such as kinship. Our definition (and this paper) excludes diverse conglomerates that are controlled centrally by a corporation, as well as socially connected firms (such as Japanese keiretsu), where there is no centralized control.

Companies benefit from participating in FBG in several ways - i.e., through access to low-cost financial resources, facilitated access to raw materials and markets, investment sharing in research and development; and generally, through gains in scale in several activities, such as hiring services and personnel training. Singh and Gaur (2009) point out that in countries such as China and India, member companies of FBG share great reputation and prestige beyond the benefits that good relationships with governments can provide.

FBG practically do not exist in developed countries (Hoskisson, Johnson e White, 2005), with rare exceptions, such as in Sweden (COLLIN, 1998), Israel (MAMAN, 2002), and Japan (AOKI, 1990). Some theories have sought to explain FBG formation: the Institutional Theory (KHANNA; PALEPU, 2000; LEFF, 1978); Political Economy (SCHNEIDER, 2009); Sociology (GRANOVETTER, 1994); and the Resource-based View (GUILLÉN, 2000). All of these theories present mechanisms, at times complementary, that provide reasons for the existence of FBG in emerging economies.

The Institutional Economics Theory has been used frequently as a theoretical framework in international business studies (PENG; WANG; JIANG, 2008; WAN; HOSKISSON, 2003). Institutions are broadly defined as any type of existing limitation or restriction to interactions between people (NORTH, 1990). However, institutions provide a framework of incentives and restrictions to exchanges of any nature, not only mercantile exchange. Hence, 
institutional power is exercised not only in economic (NORTH, 1990) and political (HENISZ, 2000) relationships but also in social norms and cultural codes (WILLIAMSON, 2000). The combined effect of incentives and restrictions is reflected in the decision-making of economic agents.

Brazil, as well as other emerging countries, has partially adhered to the international economic standards collectively known as the Washington Consensus (WILLIAMSON, 2004). This limited adherence to the Washington Consensus has meant that the Government still exerts a lot of influence on the economy and corporations. In this context, there is scarce literature on company-government relationships. Hence, the present study investigates the ownership structure of FBG, its relation to the institutional environment and sets forth propositions for future studies.

This article is outlined as follows: firstly, we've provided a theoretical review of FBGs, evidencing their economic power; secondly, we've discussed the importance of the institutional environment of organizations; thirdly, we've outlined the characteristics of the ownership structure of FBGs; and, lastly, we've discussed the influence of the Government as an institution and set forth propositions for furthering this study.

\section{FAMILY BUSINESS GROUPS}

Over the last decade, there has been significant research on FBGs and their performance (CARNEY; GEDAJLOVIC; HUEGENS; VAN ESSEN; VAN OSTERHOUT, 2011). Renowned journals have been publishing studies targeting the FBG phenomenon. Some aspects of this research body are consensual, such as the fact that they are a type of organizational configuration unlike conglomerates or multinationals (DAVIS; DIEKMAN; TINSLEY, 1994). Another important aspect commonly noted in studies about FBGs is their ability to overcome market and legal structure drawbacks, as well as ineffective regulations (GUILLÉN, 2000; LEFF, 1978).

There is no single definition of FBG. The functional definition of FBG adopted for the purpose of this study is the one proposed by Khanna and Rivkin (2001). They defined FBG as groups of legally independent companies, connected by a set of formal and informal links, which make coordinated decisions. A similar definition is observed in the study performed by Della Piana, Vecchi, and Cacia (2012).

There is no consensus among empirical studies on the global effect of FBG on the economy and society (FISMAN; KHANNA, 2004; GRANOVETTER, 2005). Several authors have tried to compare the economic benefits against the problems caused by emerging oligopolies, expropriation of minority stockholder wealth, and relationships with governments (CLAESSENS; DJANKOV; LANG, 2000; GRANOVETTER, 2005; KHANNA; YAFEH, 2007; PEROTTI; GELFER, 2001). Results are not conclusive, as there are cases in which the effects of FBG are beneficial to 
society, as well as cases in which they are not so.

There is no consensus on the benefits of FBG affiliation either. When a firm is affiliated with an FBG, it can benefit from its vertical and horizontal diversification in order to acquire a rich flow of information that improves its resource allocation (GUILLÉN, 2000). Further, scarce and expensive resources can be shared among affiliated firms and reduce its cost; skilled labor and talented management are some examples (CHANG; HONG, 2000). Intra FBG can offer even wider benefits: Granovetter (2005) lists rich tacit and formal information exchange, uncertainty reduction, contract enforcement, and opportunity identification. Luo and Chung (2005) pointed out that business opportunities may arise from ongoing relations among affiliated firms.

On the other hand, FBG affiliated firms may face some drawbacks. Agency problems derived from family control and conflict of interests among minority owners may reduce affiliated firms' profits. (MORCK et al., 2005). Besides, Cestone and Fumagalli (2005) alert that major shareholders may transfer funds or assets to affiliates in which they hold greater equity (tunneling). It is extremely difficult to track nontrade financial moves, even for minor shareholders.

Carney et al. (2011) claim that there are four issues generally addressed in studies involving FBG, which outline performance and strategy: FBG performance; the institutional environment effect; aggregation strategy of FBG firms; and the study's level of analysis.

In regard to the performance of FBG-affiliated companies, some authors defend that member firms perform better and provide empirical results (ALMEIDA; WOLFEZON, 2006; CHANG; HONG, 2000; GUILLÉN, 2000; LUO; CHUNG, 2005; MAHMOOD; MITCHELL, 2004). Some authors provide empirical results that demonstrate that the effect of affiliation is not significant (CLAESSENS; FAN; LANG, 2006; LEE; PENG; LEE, 2008). The third group of authors believes that certain FBG-affiliated firms perform better at the expense of other affiliates (BERTRAND; MEHTA; MULLAINATHAN, 2002; JOHNSON; LA PORTA; SILANES; SHLEIFER, 2000; KHANNA; YAFEH, 2007). The empirical analysis of Chilean Family Business Groups performed by Torres, Bertín, \& López-Iturriaga (2017) found that higher separation levels between ownership rights and control rights decrease FBG performance. In other words, there is no consensus in regard to the impact of belonging to an FBG on affiliated companies' performance.

The second question derives from the first and concerns the effect of the institutional environment on the performance of FBG associate firms. The most commonly accepted notion is that FBG member companies perform better when market failures in their environment proliferate (KHANNA; PALEPU, 1997). However, empirical studies about this notion, such as those by Khanna and Rivkin (2001), who suggest that studies on this topic require further data and should explore the issue in more depth, are also not conclusive.

The third question concerns the strategies adopted by companies that become 
members of FBG, such as in mergers and acquisitions. There are not many empirical studies that seek to understand the strategies adopted by companies upon entering an FBG or whether such strategies differ from other companies' in their industry. Exceptions include Colpan (2006) and Lamin (2012). Understanding these strategies could shed light on the two previous questions.

The fourth addresses level of analysis among studies. The vast majority of studies address FBG research from the perspective of the firm. Although there are a few exceptions (CHANG; HONG, 2002; LUO; CHUNG, 2005; MAHMOOD; MITCHELL, 2004), FBG are usually not the unit of analysis of empirical studies. This restraint is partly due to how difficult it is to obtain consolidated data on FBG. Carney et al. (2011) believe there to be a discrepancy among theories that approach FBG as a phenomenon and empirical studies that only analyze performance on the firm level.

The present study aims to focus on investigating the effect of institutional change among FBG (fourth question), considering the whole FBG as its unit of analysis (second question).

\section{RELEVANCE OF THE INSTITUTIONAL ENVIRONMENT}

Organizational studies have emphasized institutional power and its impact on company strategies (HENISZ, 2000; NEWMAN, 2000; PENG; LEE; WANG, 2005; PENG; WANG; JIANG, 2008). Some authors have returned their attention to institutional changes and how companies respond to this type of environmental change (HENISZ, 2000; HOFFMAN, 1999; NEWMAN, 2000; PENG, 2003). One of the consequences of institutional changes is their effect on the costs associated with company performance within economic, political, and social contexts (AOKI, 1990; NORTH, 1990). Institutions may exercise great influence on national economic performance, and the institutional theory proposes structured ways of analyzing this effect.

Studies concerning the institutional environment confirm that resource allocation among companies is affected by the conditions of this environment, as well as governance practices (AGUILERA; JACKSON, 2003; LA PORTA; LOPEZ-DE-SILANES; SHLEIFER, 1999). These studies suggest that when institutions are more efficient, companies tend to maintain more transparent governance practices and more efficient resource allocation processes.

Additional research on the institutional environment reveals its dynamic character. Such scholars aim is to identify how changes take place and the ways in which companies react to them (GREENWOOD; HININGS, 1996; HOFFMAN, 1999; KIM; KIM; HOSKINSSON, 2010; NEWMAN, 2000; PENG, 2003; THORNTON, 2002).

Empirical studies are paramount. Thomsen and Pedersen (2000) warn that the 
majority of studies on ownership structures are based on data from American and British companies. Hence, their findings are not necessarily applicable to other parts of the world. The institutional and legal environments differ greatly from that of the United States and the United Kingdom. The non-validity of empirical results obtained in samples limited to the two aforementioned countries has also been discussed by Shleifer and Vishny (1997) and La Porta et al. (1997), who suggest the need for such studies to be validated in other countries.

\section{OWNERSHIP STRUCTURE}

Ownership concentration is one of the main characteristics of Family Business Groups. Traditionally, the literature on ownership structure has been dedicated to analyzing the effect of concentrating ownership on some dimension of firm performance or its value. Harold Demsetz (1983) was one of the first authors to analyze ownership structure determinants and to suggest their relevance to firm performance assessment. The initially proposed determinants were: firm size; potential gains from centralized control; and system regulation (DEMSETZ; LEHN, 1985).

Firm size is relevant because it generates gains in scope and scale, which may contribute to increasing firm value. The more a firm is worth, the greater the risks taken by its controllers to maintain it. However, if owners are risk-averse, increased company value should contribute to reducing ownership concentration. Increased capital costs due to risk suggest that controllers maintain the lowest possible level of participation, thus reducing concentration.

The second determinant of ownership structure pointed out by Demsetz and Lehn (1985) refers to potential gains enabled by centralized control. Fewer controllers mean more control and monitoring of management actions, reducing losses due to internal conflicts and transaction costs associated with acquiring and maintaining firm control.

The third determinant, i.e., system regulation, limits the range of actions available to owners and may reduce the actions available to management. For owners, albeit free, regulation is a mechanism of self-imposed control that helps them monitoring management. However, regulation is also a risk factor, and the uncertainty associated with this activity may lead to reduced concentration, which is the case when the company is valued.

Ownership concentration, as seen in FBG, may be viewed as a means of settling agency conflicts in large companies (SHLEIFER; VISHNY, 1997). Stockholders with relevant participation in the company tend to take on the role of monitoring management performance; this is not appealing to minority stockholders due to the high costs involved.

Two agency conflicts emerge in regards to how minority stockholders are positioned within concentrated ownership companies: the traditional principal-agent problem, as 
described by Jensen and Meckling (1976), and the conflict among stockholders (principalprincipal), whereby majority stockholders may appropriate profits from minority stockholders in several ways, such as incurring in expenses to suit their own interests, biased choice of the board and their dividend policy (FAMA; JENSEN, 1983; LA PORTA; LOPEZ-DE-SILANES; SHLEIFER, 1999).

Ownership concentration is not the only relevant dimension when determining a company's ownership structure; owner identity is equally relevant (SHORT, 1994; THOMSEN ; PEDERSEN, 2000). The classification proposed by Demsetz and Lehn (1985) sets forth two categories, namely individual or family owners and institutional investors. Thomsen and Pedersen's study (2000) determined the influence of stockholder identity on company strategy and performance. Their study considered five owner categories: individual or family; financial institutions, non-financial companies, institutional investors, and Government, which is the subject of the next topic.

\section{GOVERNMENT INFLUENCE}

In this section, we outline propositions that may be used to test categories and the level of concentration of FBG ownership structure, as well as their relationships with the Government as an institution.

The Government has a great influence on the corporate environment, not only through the tax burden imposed on the private sector but also through company equity. This involvement may be direct in-state companies and indirect, through pension funds from state companies and State Banks aimed at boosting economic development. It is not unusual for governments in emerging countries to be heavily involved in the economy, which is the case in China (SINGH; GAUR, 2009; LEE; KANG, 2010).

Lazzarini (2007) studied ownership networks in Brazil from 1995 to 2003 and observed significant Federal Government participation in companies, even after a privatization cycle during the 1990s. The study further claims that the Privatization Program (Programa de Privatizações) strengthened the position of Brazilian owners, elevating state company pension funds and the Federal Government to prominent positions.

Hoskisson, Johnson, Yiu, and Wan (2001) point out that when governments are FBG stockholders, they tend to expand through diversification. This diversification usually stems from governments' interest in boosting the availability of the workforce, in pursuing noncommercial interests, and their limited capacity to monitor the activities of such groups. This effect, however, was not observed in India, which suggests that the institutional environment influences the decisions of companies in which the Government is a stockholder (RAMASWAMY; LI; VELIYATH, 2002). 
Empirical findings by Andrews and Dowling (1998) from privatized companies across 15 countries indicate that when the Government has stockholder participation in the company, certain aspects of these companies, such as performance, differ from other companies in their respective industries. However, the fact that the Government is a direct or indirect owner in FBG should moderate the effect of institutional reforms on the importance of FBG; this is one of the very propositions that the present study seeks to investigate. This effect should be observed when the Government is a minority partner or when it has indirect control.

Hence, the existing literature is the base for the following proposition:

Proposition 1: The ownership structure of Family Business Groups, which includes the level of concentration and ownership category, tends to be less concentrated as market institutions evolve.

The effect of a good relationship with governors and legislators on companies has been noted in several academic studies and is the topic of further research (BANDEIRA-DEMELLO; MARCON, 2008; BANDEIRA-DE-MELLO; MARCON; ALBERTON, 2008; VAALER, 2008). Schneider (2010) points out that business community investment practices, such as associations, consulting councils, legislative lobbies, campaign financing, and networking are outdated.

One of the ways in which FBG forge relationships with economic agents is by donating to political campaigns. Other means of establishing relationships include family or friendship ties, as well as the involvement of politicians or people related to them in running the company or board positions. Such relationships may translate into privileged access to information and political leaders, as well as legislative processes (CLAESSENS; FEIJEN; LAEVEN, 2008; SCHULER; REHBEIN; CRAMER, 2002).

However, FBG's political connections may affect the results of the propositions tested, and control mechanisms for this effect must be foreseen. Hence, the following proposition emerges from the goal of investigating the effects of FBG-government relationships:

Proposition 2: The political connections of the FBG have a moderating effect on the relationship between the institutional environment and ownership structure: the stronger the political connections, the lesser the effect of the institutional environment on ownership structure.

In order to test these propositions, we suggest choosing an environment that combines oscillations in the institutional environment and the presence of Family Business Groups. Despite the fact that these propositions could potentially be tested in other emerging economies of the BRIC (Brazil, Russia, India, China, and South Africa), Brazil shall continue to be the chosen object of the present study.

Finally, we want to stress that the greatest challenge for research is determining the metrics that best capture ownership structure, based on the limited availability of consolidated 
data on Family Business Groups.

A more in-depth analysis of the topic of this study shall contribute to an understanding of the effects of institutional changes on the Brazilian economy, its drawbacks, and the benefits obtained by FBG through political strategies. Likewise, it shall shed light on FBG governance adaptations in regards to ownership structure and relevant relationships between FBG and institutions (Government); mutual dependence between FBG and the Government, neutralization through political connections, the Government's institutional strategy as an affluent party with interests in FBG performance, as well as its direct and indirect involvement in the ownership structure of member firms of these groups.

\section{REFERENCES}

AGUILERA, R. V.; JACKSON, G. The cross-national diversity of corporate governance: Dimensions and determinants. Academy of Management Review, v. 28, n. 3, p. 447-465, 2003.

ALMEIDA, H.; WOLFENZON, D. Should business groups be dismantled? The equilibrium costs of efficient internal capital markets. Journal of Financial Economics, v. 79, n. 1, p. 99-144, 2006.

ANDREWS, W. A; DOWLING, M. J. Explaining performance changes in newly privatized firms. Journal of Management Studies, v. 35, n. 5, p. 601-617, 1998.

AOKI, M. Toward an economic model of the Japanese firm. Journal of Economic Literature, $v$. 28, p.1-27, 1990.

BANDEIRA-DE-MELLO, R.; MARCON, R. The contingent value of business group affiliation: the case of debt financing in Brazil. Encontro Anual da ANPAD 32. Anais. Rio de Janeiro: ANPAD, 2008.

BANDEIRA-DE-MELLO, R.; MARCON, R.; ALBERTON, A. Drivers of discretionary firm donations in Brazil. Brazilian Administration Review, v. 4, n. 5, p. 275-288, 2008.

BERTRAND, M.; MEHTA, P.; MULLAINATHAN, S. Ferreting out tunneling: an application to Indian business groups. The Quarterly Journal of Economics, v. 117, n. 1, p. 121-148, 2002.

CARNEY, M.; GEDAJLOVIC, E.; HUEGENS, P.; VAN ESSEN, M.; VAN OOSTERHOUT, J. Business group affiliation, performance, context, and strategy: A meta-analysis. Academy of Management Journal, v. 54, n. 3, p. 437-460, 2011.

CASANOVA, L. Global Latinas: Latin America's emerging multinationals. Nova York: Palgrave Macmillan, 2009.

CHANG, S. J.; HONG, J. Economic performance of group-affiliated companies in Korea: intragroup resource sharing and internal business transactions. The Academy of Management 
Journal, v. 43, n. 3, p. 429-448, 2000.

CHANG, S. J.; HONG, J. How much does the business group matter in Korea? Strategic Management Journal, v. 23, n. 3, p. 265-274, 2002.

CLAESSENS, S.; DJANKOV, S.; LANG, L. H. P. The Separation of Ownership and Control in East Asian Corporations. Journal of Financial Economics, v. 58, n. 1, p. 81-112, 2000.

CLAESSENS, S.; FEIJEN, E.; LAEVEN, L. Political Connections and preferential access to finance: the role of campaign contributions. Journal of Financial Economics, v. 88, n. 3, p. 554-580, 2008.

CLAESSENS, S.; FAN, J. P. H.; LANG, L. H. P. The Benefits and Costs of Group Affiliation: Evidence from East Asia. Emerging Markets Review, v. 7, n. 1, p. 1-26, 2006.

COLLIN, S. O. Why are these islands of power found in the consciousness of oceans of ownership: institutional and governance hypotheses explaining the existence of business groups in Sweden. Journal of Management Studies, v. 35, p. 719-746, 1998.

COLPAN, A. M. Dynamic effects of product diversity, international scope, and keiretsu membership on the performance of Japan's textile firms in the 1990s. Asian Business \& Management, v. 5, n. 3, p. 419-445, 2006.

DAVIS, G. F.; DIEKMAN, K.; TINSLEY, C. H. The decline and fall of the conglomerate firm in the 1980s: The deinstitutionalization of an organizational form. American Sociological Review, $v$. 59, p. 547-570, 1994.

DELLA PIANA, B.; VECCHI, A.; CACIA, C. Towards a better understanding of Family Business Groups and their key dimensions. Journal of Family Business Strategy, v. 3, n. 3, p. 174-192, 2012.

DEMSETZ, $\mathrm{H}$. The structure of ownership and the theory of firm. Journal of Law and Economics, v. 26, p. 375-390, 1983.

DEMSETZ, H.; LEHN, K. The Structure of Corporate Ownership: Causes and Consequences. Journal of Political Economy, v. 93, n. 6, p. 1155-1177, 1985.

FAMA, E. F.; JENSEN, M. C. Agency problems and residual claims. Journal of Law and Economics, v. 26, n. 2, p. 327-349, 1983.

FISMAN, R.; KHANNA, T. Facilitating development: the role of business groups. World Development, v. 32, p. 609-628, 2004.

GHEMAWAT, P.; KHANNA, T. The nature of diversified business groups: A research design and two case studies. Journal of Industrial Economics, v. 46, p. 35-61, 1998.

GHOSH, S. Affiliation and firm performance: Evidence from Indian business groups. The Manchester School, v. 78, n. 3, p. 183-200, 2010. 
GRANOVETTER, M. Business groups. In: N. J. SMELSER; R. SWEDBERG (Eds.), The handbook of economic sociology. p. 453-475. Princeton, NJ: Princeton University Press, 1994.

GRANOVETTER, M. Business Groups and Social Organization. In: SMELSER, N. J.; SWEDBERG, R. (Eds.). Handbook of Economic Sociology. 2. ed. Princeton, NJ: Princeton University Press and Russell Sage Foundation, 2005.

GREENWOOD, R.; HININGS, C. R. Understanding radical organizational change: Bringing together the old and the new institutionalism. Academy of Management Review, v. 21, n. 4, p. 1022-1054, 1996.

GUILLÉN, M. F. Business groups in emerging economies: a resource-based view. Academy of Management Journal, v. 43, p. 362-380, 2000.

HENISZ, W. J. The Institutional environment for economic growth. Economics and Politics, $v$. 12, n. 1, p. 1-31, 2000.

HOFFMAN, A. J. Institutional evolution and change: environmentalism and the US chemical industry. Academy of Management Journal, v. 42, n. 4, p. 351-371, 1999.

HOSKISSON, R. E.; JOHNSON, R. A.; WHITE, R. E. Diversified Business Groups and Corporate Refocusing in Emerging Economies. Journal of Management, v. 31, n. 6, p. 941-965, 2005.

HOSKISSON, R. E.; JOHNSON, R. A.; YIU, D.; WAN, W. P. Restructuring strategies of diversified business groups: differences associated with country institutional environments. In: HITT, M A.; FREEMAN, E.; HARRISON, J. S. (Eds.). The Blackwell handbook of strategy. p. 433-463. Oxford, UK: Blackwell Publishing, 2001.

JENSEN, M. C.; MECKLING, W. Theory of firm: managerial behavior, agency costs and ownership structure. Journal of Financial Economics, v. 3, n. 4, p. 305-360, 1976.

JOHNSON, S.; LAPORTA, R.; SILANES, F.; SHLEIFER, A. Tunneling, American Economic Review. Papers and Proceedings, v. 90, n. 2, p. 22-27, 2000.

KHANNA, T.; PALEPU, K. Why focused strategies may be wrong for emerging markets. Harvard Business Review, v. 75, p. 3-10, 1997.

KHANNA, T.; PALEPU, K. The future of business groups in emerging markets: Long-run evidence from Chile. Academy of Management Journal, v. 43, p. 268-285, 2000.

KHANNA, T.; PALEPU, K. Is Group Affiliation Profitable in Emerging Markets? An Analysis of Diversified Indian Business Groups The Journal of Finance, v. 55, n. 2, $2000 \mathrm{~b}$.

KHANNA, T.; RIVKIN, J. Estimating the performance effects of business groups in emerging markets. Strategic Management Journal, v. 22, p. 45-74, 2001.

KHANNA, T.; YAFEH, Y. Business groups in emerging markets: paragons or parasites? Journal of Economic Literature, v. 45, n. 2, p. 331-372, 2007. 
KIM, H.; KIM, H.; HOSKISSON, R. E. Does market-oriented institutional change in an emerging economy make business-group-affiliated multinationals perform better? An institution-based view. Journal of International Business Studies, v. 41, p.1141-1160, 2010.

LAMIN, A. The Business Group as an information resource: an investigation of business group affiliation in the Indian software services industry. Academy of Management Journal, 2012.

LAPORTA, R.; LOPEZ-DE-SILANES, F.; SHLEIFER, A. Corporate ownership around the world. Journal of Finance, v. 54, p. 471-517, 1999.

LAPORTA, R.; LOPEZ-DE-SILANES, F.; SHLEIFER, A.; VISHNY, R. Legal determinants of external finance. Journal of Finance, v. 52, p. 1131-1150, 1997.

LAZZARINI, S. G. Mudar tudo para não mudar nada: análise da dinâmica de redes de proprietários no Brasil como "mundos pequenos". RAE-eletrônica, v. 6, n. 1, p. 120-137, 2007.

LEE, K.; KANG, Y. Business groups in China. In: COLPAN, A. M.; HIKINO, T.; LINCOLN, J. R. (Org.). The Oxford Handbook of Business Groups. (pp. 210-236). Oxford, United Kingdom: Oxford University Press, 2010.

LEE, K.; PENG, M. W.; LEE, K. From diversification premium to diversification discount during institutional transitions. Journal of World Business, v. 43, p. 47-65, 2008.

LEFF, N. Industrial organization and entrepreneurship in the developing countries: The economic groups. Economic Development and Cultural Change, v. 26, p. 661-675, 1978.

LUO, X.; CHUNG, C. N. Keeping it all in the family: the role of particularistic relationships in Business Group performance during institutional transition. Administrative Science Quarterly, v. 50, p. $404-439,2005$.

MAHMOOD, I. P.; MITCHELL, W. Two faces: effects of business groups on innovation in emerging markets. Management Science, v. 50, n. 10, p. 1348-1365, 2004

MAMAN, D. The emergence of business groups: Israel and South Korea compared. Organization Studies, v. 23, p. 737-58, 2002.

NEWMAN, K. L. Organizational transformation during institutional upheaval. Academy of Management Review, v. 25, n. 3, p. 602-619, 2000.

NORTH, D. C. Institutions, Institutional Change and Economic Performance. Cambridge, MA: Cambridge University Press, 1990.

PENG, M. W. Institutional transitions and strategic choices. Academy of Management Review, v. 28, n. 2, p. 275-296, 2003.

PENG, M. W.; LEE, S; WANG, D. Y. L. What determines the scope of the firm over time? a focus on institutional relatedness. Academy of Management Review, v. 30, n. 3, p. 622-633, 2005. 
PENG, M. W.; WANG, D. Y. L; JIANG, Y. An institution-based view of international business strategy: a focus on emerging economies. Journal of International Business Studies, v. 39, p. 920-936, 2008.

PEROTTI, E. C.; GELFER, S. Red Barons or Robber barons? Governance and investment in Russian financial-industrial groups. European Economic Review, v. 9, p. 1601-1617, 2001.

RAMASWAMY, K.; LI, M.; VELIYATH, R. Variations in ownership behavior and propensity to diversify: a study of the Indian corporate context. Strategic Management Journal, v. 23, n. 4, p. 345-358, 2002.

SCHNEIDER, B. R. A comparative political economy of diversified business groups. Review of International Political Economy, v. 23, n. 26, p. 1-24, 2008.

SCHNEIDER, B. R. A comparative political economy of diversified business groups, or how states organize big business. Review of International Political Economy, v. 16, n. 2, p. 178-201, 2009.

SCHNEIDER, B. R. Politics in Latin America. 2010. In: COLPAN, A. M.; HIKINO, T.; LINCOLN, J. R. (Org.). The Oxford Handbook of Business Groups. p. 307-329. Oxford, UK: Oxford University Press, 2010.

SCHULER, D.; REHBEIN, K; CRAMER, R. Pursuing strategic advantage through political means: a multivariate approach. Academy of Management Journal, v. 45, n. 4, p 659-672, 2002.

SHLEIFER, A.; VISHNY, R. A survey of corporate governance. Journal of Finance, v. 52, n. 2, p. 737-783, 1997.

SHORT, H. Ownership, control, financial structure and the performance of firms. Journal of Economic Surveys, v. 8, n. 3, p. 203-249, 1994.

SINGH, D.; GAUR, A. Business group affiliation, firm governance, and firm performance: evidence from China and India. Corporate Governance, v. 17, n. 4, p. 411-425, 2009.

THOMSEN, S.; PEDERSEN, T. Ownership structure and economic performance in the largest European companies. Strategic Management Journal, v. 21, n. 6, p. 689-705, 2000.

THORNTON, P. H. The rise of the corporation in a craft industry: conflict and conformity in institutional logics. Academy of Management Journal, v. 45, n. 1, p. 81-101, 2002.

TORRES, J. P.; BERTÍN, M. J.; LÓPEZ-ITURRIAGA, F. J. Corporate control and firm value: The bright side of business groups. Journal of Family Business Strategy, v. 8, n. 2, p. 99-108, 2017.

VAALER, P. M. How do MNCs vote in developing country elections? Academy of Management Journal, v. 51, n. 1, p. 21-43, 2008.

WAN, W.; HOSKISSON, R. Home country environments, corporate diversification strategies, and firm performance. Academy of Management Journal, v. 46, n. 1, p. 27-45, 2003. 
WILLIAMSON, O. The New Institutional Economics: Taking Stock. Looking ahead. Journal of Economic Literature, v. 38, n. 3, p. 595-613, 2000.

WILLIAMSON, O. A short history Washington consensus. In: From the Washington consensus towards a new global governance. p. 24-25. Barcelona: Fund. CIDOB, 2004.

YIU, D.; BRUTON, G.; LU, Y. Understanding business groups performance in an emerging economy: acquiring resources and capabilities in order to prosper. Journal of Management Studies, 42(1): 183-206, 2005. 